\title{
sciendo
}

DOI 10.2478/sbe-2019-0057

SBE no. 14(3) 2019

\section{MEASURING FIRM AND SECTOR EFFICIENCY IN \\ PAKISTAN: AN APPLICATION OF DATA ENVELOPMENT ANALYSIS}

\author{
TOUQEER SAHER \\ COMSATS Institute of Information Technology, Islamabad, Pakistan \\ MUHAMMAD ASAD SALEEM MALIK \\ NUML Islamabad, Pakistan \\ SAIF ULLAH \\ SZABIST Karachi, Pakistan \\ ATTA ULLAH \\ Huazhong University of Science and Technology, Wuhan, China
}

\begin{abstract}
:
This study aims to determine the firm and sector efficiency using data envelopment analysis for 121 listed firms, 3 from 2004 to 2016. Based on the efficiency score of 1 and 0, DEA analysis results indicate that $10 \%$ firm was highly efficient in the whole sample, $80 \%$ are semi-efficient in selected sectors and $10 \%$ slightly inefficient. Thus, we can conclude that all firms are not equally efficient. Also, the study used a Logit/ Probit Regression model, and results indicate that the brand value and type of sector has a positive impact on firm efficiency. The study concludes that Brand value increases firm efficiency, so managers should put more focus on building firm brand value.
\end{abstract}

Key words: Firm Efficiency, Sector Efficiency, Data Envelopment Analysis, Brand Value, Growth

\section{Introduction}

Efficiency and productivity terms are used synonymously. Lovell (1993) describes productivity as the ratio between outputs and inputs. This ratio can easily be computed if single input and output are involved.

Similarly, if multiple inputs and outputs are involved, then productivity will be the ratio of all these inputs and outputs. Although efficiency and productivity have a similar meaning, different authors have defined efficiency in different ways. For instance, Cooper Seiford and Tone (2000) defined both productivity and efficiency as 
the ratio between output and input. Lovell (1993) defined efficiency in terms of the difference between actual and observed. Grmanová and Ivanová, (2018) reported that efficiency score allows the transformation of efficiency multiple inputs into multiple outputs. The comparison of how using a given input can help to achieve maximum potential output or in other words, how can you reduce the given level of inputs to make current outputs.

Measures of efficiency provide clear picture than productivity because efficiency evaluation helps to find how much an underlying subject is efficient concerning best performers and find a possible solution to fill the gap. Efficient firms can likewise be characterized as those organizations that deliver the most extreme amount of yield from a given amount of information (Enos, 2007). When it comes to measuring the efficiency of firms, differences in banking efficiency depend upon the degree of economic development (Stavarek, 2006). Some firms are efficient in respect to their waste management, and this helps them to be efficient like many efficient textile firms are considered efficient as they show concern for cleaning the waste of their manufacturing units and that is mainly due to regulatory measures. At some stage of growth, firms have to incur expenses to stay alive and survive in the competitive environment likewise Memon and Tahir (2012), analyze the degree of efficiency of firms in Pakistan using financial ratios and find that higher expense may be due to slow growth rate of investment or expense behavior theory. The efficiency of firms is different at different stages of operations (Kirkulak \& Erdem, 2014).

The focus of this study is mainly efficiency, where we see that firm-level efficiency is affected by its input/output resources. As far this study concerned, mostly shock impacts of global finance has been explored for financial sectors and on the stock, exchange say KSE-100, but no research finds the effects of efficiency and crisis on manufacturing, services, and another sector wise efficiency of Pakistan as per evidence available and best of our knowledge. Data Envelopment Analysis (DEA) is one of the best approaches for efficiency analysis and natural ranking of units under analysis. The DEA model has the advantage of minimal specification error. DEA allows the use of multiple inputs and outputs (Golshani, Khoveyni, Valami \& Eslami, 2019) and in similar argued by the (Cyrek, 2017). DEA also produces detailed information on the efficiency of the unit, and not only compares its efficiency with other units but also with its peers (Hawdon, 2003). Due to these advantages, DEA is used in this study to find efficient units within each sector and to rank them. This study also measures the association of the firm-specific variables with firm efficiency in different sectors in Pakistan.

The study focuses on the resource-based analysis of firms, so this study provides an accurate picture of how much a firm is efficient in using its inputs to produce outputs. Our firm sample size is taken from those sectors that are comprised of almost more than $50 \%$ of the market capitalisation Of Pakistan Stock Exchange; thus, we can generalize the overall efficiency of firms. This study is organized as follows; the next section reviews relevant literature, following section summarizes methodology used to conduct analysis, data collection sources, followed by results and discussions with the conclusion. 


\section{Literature Review}

Determining how finely firms utilize inputs is an appealing issue for efficiency measurement and benchmarking. The inputs are labor and capital, which help obtain outputs, for instance; produced units. Thus, this can only be done by efficiency measurement of the units. In the next sections, the concepts of firm-level and sector level efficiency are discussed.

\subsection{The Concept of Firm-Level Efficiency}

Efficiency can be defined as the ratio between output and input (Cooper, Seiford \& Tone, 2000). Lovell (1993) defined efficiency in terms of the difference between actual and observed. Rezaie, Dalfard, Shirkouhi, and Shirkouhi (2012) find that fuzzy DEA analysis is the best measure for efficiency analysis of firms. Afonso, Schuknecht, and Tanzi (2010) evaluate the efficiency of the public sector and conclude that there is diversity, in comparison with a group of tops performing Asian emerging markets, in spending performance among new EU member countries. If Expense/ revenue ratio is considered, new entrants in markets take advantage of their peers; thus, their expense efficiency is higher than the ones already in market and expenditure efficiency increases as long as you operate in a stable market.

As for the size of the firm is concerned, Majumdar (1997) investigate a large sample of 1,020 Indian firms to know whether the age and size have any impacts upon the firms' economic performance in the industry data of Indian firms. The findings of the study suggest there is a negative relationship between size and productivity and positive relation among size and profitability. Olatubi and Dismukes (2000) point out, after analyzing the cost efficiency of coal-fired power plants, the influence of size, and technology and fuel type upon operating efficiency. Similar, Moutsianas and Kosmidou (2016) found that large size reduces cost and ability to gather information for the running of the business. To evaluate the performance of SMEs of Australian tobacco, beverages, and food manufacturing markets, Kotey and Donnell (2002) apply Data Envelopment Analysis (DEA). The GDP per capita and size, according to Kapelko and Lansink(2015) has a positive relationship with technical effectiveness. Technical efficiency is the assessment of the resources' (inputs) vector that is used to obtain the vector of outputs and also indicates the quality of management (Rogova \& Blinova, 2018). A positive relation between profitability and size is explored by Majumdar and Chhibber (1999), while a positive relationship between efficiency and size found by (Zelenyuk \& Zheka, 2006). However, for Majumdar (1997), size positively correlates with profitability and negatively with productivity (Kipesha, 2013).

Apart from the impact of tangible assets on firm performance effect of intangible assets is also found on firm performance and growth since brands significantly influence firm efficiency. Therefore, these are valuable intangible assets and have a positive relationship with technical efficiency (Kapelko \& Lansink, 2015). An investigation made by (Park, Eisingerich, Pol \& Park, 2013) to which a firm uses its image/ brand value and the effect of the mark logo benefits on client mark duty. Luo, 
Raithel, and Wiles (2013) find that brand dispersion may lead to abnormal results and impacts stock price.

\subsection{The Concept of Sector Efficiency}

Firms perform together to influence the execution of the areas, and in this way, it is additionally critical to quantify the proficiency of parts over time. Pakistan's manufacturing sectors, to which our current research relates, has an essential role in Pakistan's economic development (Shah, 2011). Thus, it is necessary to have an idea about how efficient firm performance relates to the sector performance. As firm efficiency represents overall sectors efficiency; several studies measure firm wise efficiency and generalized their results about a given sector or economy performance. These studies include Afonso and Aubyn $(2005,2006)$ that measured effectiveness in imparting education and health in OECD nations and Gupta and Verhoeven (2001) for health and education in Africa. Afonso and Aubyn (2006) apply a two-step Tobit/DEA procedure, whereas most researches undertake the DEA analysis to assess effectiveness. For a business corporation to survive and perform, it has to be useful nowadays. Khan and Khattak (2016) study the efficiency of the banking sector by employing the DEA approach found that efficient banks ensure consistent returns.

Sigala (2003) reported that the difference between services and products is blurred due to the knowledge era; products are increasingly being in formalized while services industrialized, thereby raising the concept whether efficiency depends upon the type of sector. Mostafa (2007) favor that sector type difference has no linkage to the firm's efficiency is different among different states of Indian manufacturing sectors, and this depends upon the manufacturing output and labor quality (Mukherjee, 2008). For China, the energy efficiency of firms in the eastern, western, central province is different due to excessive input and insufficient technology and failure in achieving economies of scale (Wang, Zeng, Wei, \& Zhang, 2012). Lim (2008) find that other sectors remained inefficient and mining and tin stayed most active during the crisis, and for this, he uses rolling bi-correlation test statistic on 8sectors of Malaysian industry. Raheman, Qayyum, Afzal, and lqbal (2009) find that the sugar industry of Pakistan is not efficient that can be credited to the absence of essential administrative leadership.

\subsection{Hypothesis}

H1: All firms in manufacturing and services sectors are equally efficient.

H2: $\quad$ Firm brand value has a significant positive impact on firm efficiency.

H3: $\quad$ Firm size has a significant positive impact on firm efficiency.

H4: Firm Expense/revenue ratio has positive significant impact on firm efficiency.

H5: $\quad$ Firm rate of growth has a significant positive impact on firm efficiency.

H6: $\quad$ Type of sector has a significant positive impact on firm efficiency. 


\section{Research Methodology}

\subsection{Data Collection Sources}

To compute DEA efficiency scores for each firm we use a sample of 121 firms from textile, sugar and allied industries, chemicals, cement, commercial banks, engineering, fertilizers, food and consumer goods, oil and gas exploration and marketing sectors. These efficiency scores are calculated using input and output variables. The annual data on these variables are taken from the period of 2004 to 2016. The data sources for these variables are each company Website, Pakistan Stock Exchange website, and website of the business recorder. Data for total assets, net income, operating expenses, EPS was taken from annual reports of companies. Some of these annual reports that are not available on the company's website have been collected from Pakistan Stock Exchange website. Data for market capitalization, share price, and Common stock was taken from the website of the business recorder.

\subsection{Data Envelopment Analysis (DEA Approach)}

The attention of some researchers was diverted from the traditional approaches towards various frontier techniques. In order to evaluate the efficiency of banks there are various parametric methods plus non-parametric methods available in literature. Initially, the traditional approach is used to calculate the bank's efficiency based on financial ratios however this approach has some drawbacks, which promote to use other criteria because this method does not constitute long term effect. Frontier approach has the parametric methods which are Stochastic Frontier Approach (SFA), Thick Frontier Approach (TFA) and Distribution Free Approach (DFA) are parametric methodologies and the nonparametric methods are Data Envelopment Analyses (DEA) and Free Disposal Hull (FDH).

Despite the several techniques that are available to measure the efficiencies DEA is the latest and appropriate because DEA is a systemic non-parametric approach for the analysis of multiple inputs and outputs efficiency by creating a frontier out of them. In this model, three characteristics must be specified by users; first, returns to scale, second valuation system, and third orientation system. Returns to scale might be either constant return to scale or variable return to scale. In the case of constant returns to scale, yield changes moderately to inputs. While with variable returns to scale, modification in information prompts a disproportional change in yield. The evaluation system alludes to weights given to inputs and yields in target work, subject to disparity limitations. The orientation system can be designated as input-orientation or outputorientation. An input orientation means how much inputs can be reduced to get current optimal level outputs for a firm that can help it be DEA-efficient. While an output orientation helps to find how much we can increase our output while consuming a current level of inputs so that a firm can be one among the DEA-efficient ones.

There are a few distinct models of DEA with two most used CCR and BCC model. The CCR model used by Charles, Cooper, and Rhodes in 1978 and the second 
one is the BCC model utilized and contrived by Banker, Charnes, and Cooper in 1984 . CR model uses a constant return to scale while the BCC model uses the variable return to scale. CCR model enables DEA to reach out from single input and output to different ones. Apart from a return to scale selection, two other elements must also specify that are discussed earlier. Charnes et al. (1978) extended Farrell's (1957) strategy to various info/ yield proficiency measures as the proportion of weighted entirety of yields to weight whole of sources of info, subject to the limitation that productivity of all capable units is $\leq 1$.

The selection of BCC or CCR model depends on choice. Our review utilizes the BCC model, with a variable return to scale and input orientation with weights assigned by software. As our sample consists of manufacturing and services firms, and here inputs are the only decision variables that can be adjusted to increase or decrease outputs, therefore we use the input-oriented approach. According to Seiford and Zhu (1999), generally we count two aspects being efficient; profitability and marketability which means how efficiently a firm utilizes its assets to generate revenues, profitability; and improve its market value by generating revenues and profits, marketability. The input variables define profitability view, and output variables define the marketability view. Recently Cyrek (2017) study used input and output variables by using DEA method and also Grmanová and Ivanová (2018) used DEA model by stating that efficiency score allows and analyses the transformation of efficiency multiple inputs into multiple outputs. Our input and output variables are;

Table 3.1: Variables for Data Envelopment Analysis

\begin{tabular}{|c|c|c|c|}
\hline Input variables & Proxy & Output variables & Proxy \\
\hline Assets & $\begin{array}{l}\text { Total assets of the } \\
\text { firm }\end{array}$ & Net profit & $\begin{array}{l}\text { Net income after } \\
\text { tax }\end{array}$ \\
\hline & & & Share $\quad$ price $^{*}$ \\
\hline Employee Cost & $\begin{array}{l}\text { Employees' } \\
\text { salaries }\end{array}$ & $\begin{array}{l}\text { Market } \\
\text { capitalization }\end{array}$ & $\begin{array}{l}\text { Common Share } \\
\text { Outstanding }\end{array}$ \\
\hline Total expenses & $\begin{array}{l}\text { Operating } \\
\text { Expenses }\end{array}$ & Share price & Stock daily price \\
\hline $\begin{array}{l}\text { Total Shareholder } \\
\text { Equity }\end{array}$ & Total equity & EPS & EBITA/CSO \\
\hline
\end{tabular}

Suppose there are several DMUs (DMU1, DMU1, and DMU n) with s different outputs and $\mathrm{m}$ different inputs, DMU $\mathrm{j}\left(j^{1 / 4} 1,2, \ldots, \mathrm{n}\right)$ consumes amount $\mathrm{x} \mathrm{kj}$ $\left(k^{1 / 4} 1,2, \ldots \mathrm{m}\right)$ of input $\mathrm{k}$ to produce amount $\mathrm{y} \operatorname{rj}\left(r^{1 / 4} 1,2, \ldots, \mathrm{s}\right)$ of output $\mathrm{r}$. The linear programming in the envelopment form of an input-oriented model to evaluate the efficiency of $\mathrm{DMU}$ 。 is shown as follows:

$$
\begin{aligned}
& \min \theta-\varepsilon \sum_{k=1}^{n} S_{K}^{-}+\sum_{r=1}^{s} S_{r}^{+} \\
& \sum_{j=1}^{n} x_{k j} \lambda_{j}+s_{k}^{-}=\theta x_{k_{0}}
\end{aligned}
$$




$$
\begin{aligned}
& \sum_{j=1}^{n} y_{r j} \lambda_{j}-s_{r}^{-}=y_{r_{0}} \\
& \sum_{j-1}^{n} \lambda_{j}=1 \ldots \ldots \ldots \ldots . . . \\
& \lambda_{j}, s_{k}^{-}, s_{r}^{+} \geq 0
\end{aligned}
$$

Here $\theta$ is efficiency score for $\mathrm{DMU}_{\circ} ; \lambda$ denotes weights assigned by DEA to each input and output. A DMU is efficient if $\theta=1$ and variables of slack are 0 . When a firm intends to get, more weighted inputs to get the same amount of weighted outputs as compared to benchmark firms, then its efficiency score will be less than unity as this firm employs more inputs to get the same proportion of outputs and is not much efficient in resource utilization.

Literature present that DEA to measure firm efficiency for example firms using DEA model for evaluation of efficiencies of DMUs in the regulated sector for instance, (Banker, Charnes, \& Cooper, 1984) in the nonprofit sector. Farrell and Fieldhouse 1962, in private industry, Banker \& Maindiratta 1986, Banker \& Datar 1987). Consumers likewise advantage from adequate resources utilization and distribution since which causes lower costs furthermore, more effective organization (Anderson, \& Fok, 1998). Measuring capability levels has transformed into an essential issue for chiefs and budgetary pros alike (Galagedera \& Silvapulle, 2002). Bayraktar, Tatoglu, Turkyilmaz, Delen, and Zaim (2012) use the DEA tool to rank most favored mobile phone brands in Turkey. DEA model results ranked Nokia as the most efficient mobile phone brand, among others in Turkey. Recent studies such as Stanickova (2017), Golshani, Khoveyni, Valami, and Eslami (2019) used the DEA model of DMU's by stating that the decision-making units (DMUs) are most accepted ranking methods with higher scores.

\subsection{Logit Regression Model}

In assessing firm's effectiveness using DEA approach, Homogeneity among organizations is expected. Nonetheless, distinctions in environmental and organization particular variables, for example, extraordinary exercises performed, sort of possession, age, and date of organization recorded can present heterogeneity. These natural variables bring about contrasts crosswise over organizations regarding the multifaceted nature of giving the administration. The present study uses a discrete dependent variable model "Logit regression model" to address this with a binary type variable (logit Module, 2005). The use of Logit regression model as a second step with the DEA approach is used by (Galagedera \& Silvapulle, 2002). This model uses a dependent variable that has a value of one or zero. In the Logit model the likelihood of an event is expressed as;

$$
\begin{aligned}
& P_{i}=E\left(Y_{i}=\frac{1}{X_{i}}\right)= \\
& \text { This equation can } \\
& P_{i}=\frac{1}{1+e^{-Z i}}=\frac{e^{Z}}{1+e^{-Z i}}
\end{aligned}
$$

Where, 


$$
Z_{i}=\beta_{i}+\beta_{i} X_{i}
$$

Let $\mathrm{Pi}$ is the probability of an event. Also, (1 $\mathrm{-Pi})$ is the probability of not an event. Now consider the following model of $(1-\mathrm{Pi})$ :

So,

$$
1-P_{i}=\frac{1}{1+e^{Z i}}
$$

$\frac{P_{i}}{1-P_{i}}=\frac{1+e^{Z i}}{1+e^{-Z i}}=e^{Z i}$

The natural $\log (\mathrm{Li})$ of this ratio is called the logit, and therefore, the model is called the Logit model.

Now consider the following model:

$$
L_{i}=\ln \left(\frac{P_{i}}{1-P_{i}}\right)=Z_{i}=\beta_{i}+\beta_{i} X_{i}
$$

The logit model tells us that the log of the odds ratio is a linear function of explanatory variables. In this model, the slope coefficient $\beta i$ gives the change in the $\log$ of the odds ratio per unit change in the Xi. As our dependent variable is efficiency and this is the score given by DEA. The value of these scores is between 1 and less than 1 but greater than zero, so we have transformed all the values $\geq 1$ as 1 otherwise 0 . Further, we have determined some firm-specific variables Size (SZ), Brand value (BV), Expense/revenue ratio (E/R), Type of sector (SEC) and impact on firm efficiency if the firm is among a fast-growing list of the firm and this is denoted by (FGL). Taking these explanatory variables equation 2 becomes;

$$
\begin{aligned}
& E F F_{i t}=\alpha+\beta_{1}\left(S E C_{i t}\right)+\beta_{2}\left(B V_{i t}\right)+\beta_{3}\left(E T R_{i t}\right)+\beta_{4}(F G L)_{i t}+\beta_{5}\left(S Z_{i t}\right)+\mu_{i t} \\
& \text {..IV) }
\end{aligned}
$$

Type of Sector (SEC) being a dummy variable that has been used to demonstrate the sector of the firm in which it is operating (= 1 if the manufacturing industry; 0 otherwise). SEC is used so that we can find there any difference in the efficiency of firms operating in the service or manufacturing sector. BV is the brand value of the company. The measure for brand value is calculated by subtracting a company's 2004 equity from its 2005 market capitalization. $E / R$ ratio is expenses/revenues ratio. $\mathrm{FGL}$ is another dummy variable (= 1 if the company is among a fastest growing list of companies, 0 otherwise). Its value is the rate of change in revenue of a firm from one year to next. Total assets of a firm have been used as a proxy for the size of the firm.

\subsection{Odd Ratios}

In the logit model, using the average values of all explanatory variables, we find the odds of a firm being efficient. In this review, efficiency is our dependent variable, and its value is in 1 and 0 , so we should know the odds for each firm being efficient for each one unit increase in its particular variable. For this, we calculate Odd ratios (OR). The equation for calculating odd ratios is;

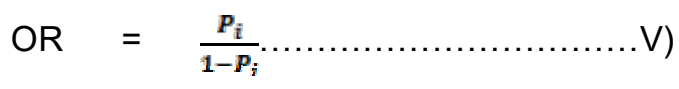

Where, 
$\left.P_{i}=e^{z} / 1+e^{z} \ldots \ldots \ldots \ldots \ldots \ldots \ldots . . . . \ldots l\right)$

\section{Results and Discussions}

\subsection{Results from DEA Analysis}

After finding the DEA scores of efficiencies for 121 firms listed in Pakistan Stock Exchange (PSX), we further classify firms in three categories;

$>$ Firms with efficiency scores of 1 throughout the sample period are classified as highly efficient.

$>$ Firms with efficiency scores of less than 1 over less than half of the sample period are classified as semi-efficient.

$>$ While firms are having scores less than 1 in more than half of the sample period are classified as inefficient.

The results indicate that the Cement sector has four firms as highly efficient with an estimated efficiency score of 1.0 while rests are semi-efficient. From the Engineering sector, all firms are almost semi-efficient. Fertilizer sector has three firms as highly efficient with an efficiency score of 1 and 0 , and only one firm is semi-efficient. Among Oil and Gas exploration sector, two firms are highly efficient, but the remaining two are semi-efficient, for Oil and Gas Marketing sector one firm remained highly skilled while rest remained semi-efficient. Among Sugar and Allied industries, almost all firms are semi-efficient, which means there is inefficient utilization of resources and findings are in line with that of Raheman, Qayyum, Afzal, and lqbal (2009). For chemical sector firms are semi-efficient to slightly inefficient? The same trend is seen for commercial banks where all banks are semi-efficient to slightly inefficient, the Textile sector has four semi-qualified firms, and consumer industry has maximum firms in the sample as, and a few are somewhat inefficient. DEA categorizes firm either efficient or inefficient, but our study has further classified firms with a score of less than 1 and 0 ; as semi-efficient and slightly inefficient and this helps us to find if the firm has efficiency scores less than 1.0 we cannot say that such firms are overall inefficient. Because there might be several reasons for a firm that it didn't perform better in a given year like earnings may decline due to fewer sales because of a substitute product or less share price because of increase in interest rates for other investment securities. So, these results reject our hypothesis $\mathrm{H} 1$ that all firms are equally efficient.

\subsection{Descriptive Statistics}

Descriptive statistics in Table 4.2 shows the mean, median, maximum, and minimum, Std., Dev. Skewness and Kurtosis. Results suggest that mean value of efficiency overall firms in our sample are efficient and mean value of Expense/revenue ratio means on average a firm spends $13.34 \%$ of its revenues to meet its operating and other expenses. The mean value of FGL shows almost 47 firms in a sample of 121 firms are among the fast-growing list which means each year percentage of growth in 
revenue for these firms is more significant than average growth in revenues of all firms in a sector. Mean value of size is (70.53) millions, shows on an average asset base of firms is 70.53 million, mean of Brand value is (234.14), but the values of size and brand value are in millions. The detailed results are demonstrated in table 4.2 below;

Table 4.2: Descriptive Statistics

\begin{tabular}{lllllcl}
\hline & EFF & ER & FGL & SEC & SZ (m) & BV (m) \\
\hline Mean & 0.74 & 13.34 & 0.47 & 0.84 & 71 & 234 \\
Skewness & -1.1 & 10.5 & 0.1 & -1.9 & 5.065 & 7.99 \\
Kurtosis & 2.2 & 174.4 & 1.0 & 4.4 & 32.11 & 83.15 \\
\hline
\end{tabular}

\subsection{Logit Regression Model Results}

The results of the logit expression are shown in Table 4.3. The results of Firm efficiency and Expense/revenue (E/R) ratio logistic regression model using equation 4. We find that Expense/revenue $(E / R)$ ratio doesn't have a significant impact on the efficiency which means that higher expense ratio doesn't necessarily impact efficiency, as the firms incur higher expense, they reap the reward later on. Afonso, Schuknecht, and Tanzi (2010) also find that expense ratio among companies depends upon their stage of development also new entrants in markets take advantage of their peers and their expense efficiency is higher than the ones already in market and expenditure efficiency increases as long as you operate in a stable market. The results of Firm efficiency and Fast-growing list (FGL) being one among the fast-growing list (FGL) negatively impacts the efficiency of firm and this impact is significant because firms in order to compete other firms may be growing at a higher pace and may earn higher profits but at the same time, they lose their efficiency.

Type of sector (SEC) impacts positively and firm efficiency significant while our findings are entirely contradicting with that of Park et al., (2013) and are in line with Mostafa, (2007) who find that impact of the type of sector is insignificant to the firm performance. Results show that brand value (BV) impacts firm efficiency positively, and this impact is found to be significant which means a firm becomes efficient as its brand value increases because brand value is developed when firms consistently develop their brand quality and thus it helps them to earn profits (Park, Maclnnis, Priester, Eisingerich \& lacobucci, 2010). Park et al. also support these findings, Gupta, Melewar, \& Bourlakis (2010); and Aaker \& Jacobson (2001). Results shows that firm size (SZ) has a negative and significant impact on firm efficiency while these finding are in line with one made by (Majumdar, 1997) who find that size of firm is negatively related to its profitability and growth as it becomes difficult for the firms to manage a large firm because then many other sources of inefficiency arises. For instance, Mostafa (2007) find that larger firms employ a more significant number of employees, thus facing higher expenses, causing efficiency. While our findings contradict that of Kapelko and Lansink (2015), Majumdar, and Chhibber, (1999), Zelenyuk and Zheka (2006) who found that 
size are positively related to firm efficiency. In table 4.3 the detailed results of the Logistic regression model shown below;

Table 4.3: Results of Logistic Regression Model

\begin{tabular}{llcll}
\hline Variable & Coefficient & Std. Error & Z-statistic & Prob. \\
\hline Expense/revenue (E/R) ratio & 0.00 & 0.00 & 0.94 & 0.34 \\
Fast-Growing list (FGL) & $-0.31^{* * *}$ & 0.11 & -2.69 & 0.00 \\
Type of sector (SEC) & $0.33^{*}$ & 0.19 & 1.75 & 0.07 \\
Firm Size (SZ) & $-1.07^{* \star *}$ & 4.08 & -2.66 & 0.00 \\
Brand Value (BV) & $5.60^{\star * *}$ & 1.90 & 2.94 & 0.00 \\
C & 0.88 & 0.19 & 4.56 & 0 \\
Prob (LR statistic) & 0.00 & & & \\
LR statistic & 35.43 & & & \\
McFadden R-squared & 0.19 & & & \\
\hline *** & & &
\end{tabular}

*** Significant at $1 \%$ level, ${ }^{* *}$ at $5 \%$ and ${ }^{*}$ at $10 \%$ level

\subsection{Probit Regression Model Results}

McFadden R-squared is 0.1968 , that means, but the probability of LR statistics is 0.00001 (see Table 4.4) and is less than 0.05 , which means independent variables can explain efficiency. These results are also robust by using Probit Regression Model (see Table No 4.4), and results suggest the same relationship of independent variables on the efficiency of firms with the dependent variable. The detailed results of the Probit regression model presented below in table 4.4 .

Table 4.4: Results of Probit Regression Model

\begin{tabular}{lllll}
\hline Variable & Coefficient & Std. Error & Z-statistic & Prob. \\
\hline Expense/revenue (E/R) ratio & 0.0006 & 0.00 & 0.98 & 0.32 \\
Fast-Growing list (FGL) & $-0.18^{\star \star *}$ & 0.06 & -2.68 & 0.00 \\
Type of sector (SEC) & $0.19^{\star}$ & 0.11 & 1.67 & 0.09 \\
Firm Size (SZ) & $-6.10^{\star \star *}$ & 2.39 & -2.54 & 0.01 \\
Brand Value (BV) & $2.93^{\star * *}$ & 9.47 & 3.09 & 0.00 \\
C & 0.55 & 0.11 & 4.67 & 0 \\
Prob (LR statistic) & 0.00 & & & \\
LR statistic & 34.97 & & & \\
McFadden R-squared & 0.19 & & & \\
\hline
\end{tabular}

${ }^{* *}$ Significant at $1 \%$ level, ${ }^{* *}$ at $5 \%$ and ${ }^{*}$ at $10 \%$ level

\subsection{Results of Odd Ratios}

In the logit regression model, we often want a measure of the unique effect of each independent variable on the dependent variable. Odd ratios provide a more meaningful interpretation of the permanent effect one independent variable has on the dependent variable as compared to probabilities. Table 4.5 shows that firm size has odds ratio value 2.248 , which indicate that the increase in firm size by $100 \%$ will decrease the chances of a firm being efficient by 2.248 times. Expense/revenue ratio 
has odds ratio value 2.425, which indicate that the increase in Expense/revenue ratio by $100 \%$ will increase the chances of a firm being efficient by 2.425 times. Brand value has odds ratio value 2.764 , which means an increase in firm brand value by $100 \%$ will increase the chances of a firm being efficient by 2.764 times.

In this study, two categorical independent variables FGL and SEC were used, and their values are between 0 and 1 . In this case, we can use unique ratio values to calculate probabilities that will be helpful to make a meaningful interpretation of these variables. These probabilities were calculated by using equation (6) for both these variables given in Table 4.5. FGL $=1$ when a firm is among the list of fast-growing companies and $F G L=0$ if a firm is not among a list of fast-growing companies. The Odd ratio of $F G L$ is 1.124 times so Odd of a firm being efficient decreases by $57.6 \%$ if that firm is from a fast-growing list of companies, i.e., $F G L=1$. SEC $=1$ if a firm belongs to the manufacturing sector and $\mathrm{SEC}=0 \mathrm{f}$ if a firm belongs to the services sector. The Odd ratio of SEC is 0.613 times so odd of a firm being efficient is $38 \%$ higher if that firm belongs to the manufacturing industry, i.e., SEC $=1$. In table 4.5 the detailed results of the Odd ratio of each variable shown below;

Table 4.5: Result of Odd Ratio of each variable

\begin{tabular}{|c|c|c|c|}
\hline Variable & Coefficient & Odds Ratio (OR) & Prob. \\
\hline $\begin{array}{l}\text { Expense/revenue }(E / R) \\
\text { ratio }\end{array}$ & 0.001 & 2.42 & 0.34 \\
\hline Firm Size (SZ) & $-1.07^{\star \star \star}$ & 2.24 & 0.00 \\
\hline Brand Value (BV) & $5.60^{* * *}$ & 2.76 & 0.00 \\
\hline $\begin{array}{l}\text { Fast-Growing list (FGL) } \\
(1,0)\end{array}$ & $-0.31^{* \star *}$ & 1.36 & 0.57 \\
\hline $\begin{array}{l}\text { Type of sector (SEC) } \\
(1,0)\end{array}$ & $0.33^{*}$ & 0.61 & 0.38 \\
\hline C & 0.88 & - & 0 \\
\hline Prob (LR statistic) & 0.00 & & \\
\hline LR statistic & 35.43 & & \\
\hline McFadden R-squared & & & \\
\hline
\end{tabular}

${ }^{* \star *}$ Significant at $1 \%$ level, ${ }^{* *}$ at $5 \%$ and ${ }^{*}$ at $10 \%$ level

\subsection{The result of Summary Results}

\section{Table 4.7: Summary Results}

\begin{tabular}{lll}
\hline S. No. & Hypothesis & Accepted/Rejected \\
\hline H1 & $\begin{array}{l}\text { All firms in manufacturing and services sectors are equally } \\
\text { efficient. }\end{array}$ & Rejected \\
H2 & $\begin{array}{l}\text { Firm brand value has a significant positive impact on firm } \\
\text { efficiency }\end{array}$ & Accepted \\
H3 & Firm size has a significant positive impact on firm efficiency & Rejected \\
H4 & $\begin{array}{l}\text { Firm Expense/revenue ratio has a significant positive impact } \\
\text { on firm efficiency }\end{array}$ & Rejected \\
H5 & $\begin{array}{l}\text { The firm rate of growth has a significant positive impact on firm } \\
\text { efficiency }\end{array}$ & Rejected \\
H6 & $\begin{array}{l}\text { Type of sector has a significant positive impact on firm } \\
\text { efficiency }\end{array}$ & Accepted \\
\hline
\end{tabular}




\section{Conclusion and Policy Implications}

The present study used Data Envelopment Analysis measure efficiency of firms in manufacturing and services sectors of Pakistan. Analysis results indicate that $10 \%$ of firms in our sample are highly efficient with the efficiency score of 1.0 throughout our sample period, $80 \%$ firms in selected sectors are semi-efficient with efficiency score less than 1.0 in less than half of sample time period and $10 \%$ slightly inefficient with efficiency score less than 1.0 in more than half of the sample period. The purpose of the study to find whether all firms in our sample are equally efficient; thus, we can conclude that all firms are not equally efficient. We also use the Logit Regression model as a second step approach and find the impact of certain firm-specific factors. Results indicate that firm size (SZ) negatively and significantly impacts firm efficiency and as the size increase efficiency may decline. Brand value (BV) has a significant positive impact on firm efficiency as a firm's brand value increases from its mean value, which indicate that efficiency increases. Expense/revenue ratio $(E / R)$ is insignificant to firm efficiency (EFF) that means a unit increases in $E / R$ does not cause an increase in (EFF). FGL negatively impacts (EFF) or in other words, one-unit change in FGL causes one-unit decrease in (EFF) as firms strive to increase the revenues so that the efficiency decline. The impact of the type of sector is positive and significant, which means efficiency is also dependent on the kind of industry.

The results are further robust using Probit Regression model. Also, it is observed that although the crunch of the crisis was not direct; Pakistan faced this as contagion as afterward shocks in 2009. Some other reasons can be attributed to the decline in performance in 2009; such as the most to be considered political instability, the decline in exports, trade, and terrorism, etc. After the death of Benazir Bhutto in 2007 a loss was reported due to public violence, a decreased in FDI was said to be $20 \%$ as investors consider Pakistan an unsafe place to invest in which reduce the performance and efficiency. In future research, a cross country comparison can be taken to know which economy is best, especially China because after integration, CPEC China economy is most relevant and influencing with Pakistan Economy sustainable socio-economic development. In light of our findings, managers should give more attention to inputs that add value to firms for instance; our study concludes that Brand value increases firm efficiency so managers should put more focus on building firm brand value. For the policymakers, investors, and economists, proactive approaches should be adopted to avoid the downfall of any economy during or after any financial or non-financial crisis. So that can help they should devise rules, regulations, and policies that help inefficient firms to be efficient like educating managers about the use of technology that reduces the cost; this will help them to use their resources efficiently. 


\section{References}

Aaker, D.A., Jacobson, R., (2001), The value relevance of brand attitude in high-technology markets. Journal of marketing research, Vol. 38 no. 4, pp. 485-493.

Afonso, A., Aubyn, M.S., (2006): Cross-country efficiency of secondary education provision: A semiparametric analysis with non-discretionary inputs. Economic Modelling, Vol. 23, no.3, pp. 476- 491.

Afonso, A., St Aubyn, M., (2005), Non-parametric approaches to education and health efficiency in OECD countries. Journal of Applied Economics, Vol. 8, no. 2, pp. 227.

Afonso, A., Schuknecht, L., Tanzi, V., (2010), Public sector efficiency: evidence for new EU member states and emerging markets. Applied Economics, Vol. 42, no. 17, pp. 21472164.

Anderson, R.I., Fok, R., (1998), The efficiency of franchising in the residential real estate brokerage market. Journal of Consumer Marketing, Vol. 15, no. 4, pp. 386-396.

Banker, R. D., Maindiratta, A., (1986), Piecewise log-linear estimation of efficient production surfaces. Management Science, Vol: 32, no. 1, pp. 126-135.

Banker, R.D., Charnes, A., Cooper, W.W., (1984), Some models for estimating technical and scale inefficiencies in data envelopment analysis. Management Science, Vol. 30, no. 9, pp. 1078- 1092.

Banker, R.D., Datar, S.M., Rajan, M.V., (1987), Measurement of productivity improvements: An empirical analysis. Journal of Accounting, Auditing \& Finance, Vol. 2, no. 4, pp. 319-347.

Bayraktar, E., Tatoglu, E., Turkyilmaz, A., Delen, D., Zaim, S., (2012), Measuring the efficiency of customer satisfaction and loyalty for mobile phone brands with DEA. Expert Systems with Applications, Vol: 39, no. 1, pp. 99-106.

Charnes, A., Cooper, W.W., Rhodes, E., (1978): Measuring the efficiency of decision-making units. European journal of operational research, Vol. 2, no. 6, pp. 429-444.

Cooper, W.W., Seiford, L.M., Tone, K., (2000): Data envelopment analysis.

Cyrek, M., (2017), Social efficiency of employment in three sectors - a comparison of Polish regions Equilibrium. Quarterly Journal of Economics and Economic Policy, Vol. 12, no.

3, pp. 417-432. doi.org/10.24136/eq.v12i3.22

Enos, D.D., (2007): Performance improvement: Making it happen. CRC Press.

Farrell, M.J., Fieldhouse, M., (1962): Estimating useful production functions under increasing returns to scale. Journal of the Royal Statistical Society. Series A (General), pp. 252267.

Galagedera, D.U., Silvapulle, P., (2002), Australian mutual fund performance appraisal using data envelopment analysis. Managerial Finance, Vol. 28, no.9, pp. 60-73.

Grmanová, E., Ivanová, E., (2018), The efficiency of banks in Slovakia: Measuring by DEA models. Journal of International Studies, Vol. 11, no. 1, pp. 257-272. doi:10.14254/2071- 8330.2018/11- 1/20

Golshani, H., Khoveyni, M., Valami, H. B., Eslami, R., (2019), A slack-based superefficiency in a two- $\quad$ stage network structure with intermediate measures. Alexandria Engineering Journal. doi.org/10.1016/j.aej.2019.01.002

Gupta, S., Verhoeven, M., (2001), The efficiency of government expenditure: experiences from Africa. Journal of policy modeling, Vol. 23, no. 4, pp. 433-467.

Gupta, S., Melewar, T.C., Bourlakis, M., (2010), Transfer of brand knowledge in business-tobusiness markets: a qualitative study. Journal of Business \& Industrial Marketing, Vol. 25 , no. 5 , pp. 395-403.

Hawdon, D., (2003), Efficiency, performance, and regulation of the international gas industry- a bootstrap DEA approach. Energy Policy, Elsevier, vol. 31, no. 11, pp. 1167-1178. 
Husain, N., Abdullah, M., Kuman, S., (2000), Evaluating public sector efficiency with data envelopment analysis (DEA): a case study in the Road Transport Department, Selangor, Malaysia. Total Quality Management, Vol. 11, no. 4-6, pp. 830-836.

Kapelko, M., Lansink, A.O., (2015), An international comparison of productivity change in the textile and clothing industry: a bootstrapped Malmquist index approach. Empirical Economics, Vol. 48, no. 4, pp. 1499-1523.

Kipesha, E.F., (2013), Impact of size and age on firm performance: evidence from microfinance institutions in Tanzania.

Kirkulak, B., Erdem, S., (2014), Market value chain efficiency in Turkey: application of DEA to the pre-and post-2001 financial crisis. EuroMed Journal of Business, Vol. 9, no. 1, pp. 2-17.

Khan, F. U., Khattak, B. K., (2016), An Empirical Investigation of Commercial Banks' efficiency in Pakistan: A Non-Parametric Data Envelopment Approach. Gomal University Journal of Research, Vol. 32, no. 1, pp. 21-32.

Kotey, B., O'Donnell, C.J., (2002), Data envelopment analysis in small and medium enterprises: A study of the Australian food, beverages, and tobacco manufacturing industry. Small Enterprise Research, Vol. 10, no. 2, pp. 3-22.

Lim, K.P., (2008), Sectoral efficiency of the Malaysian stock market and the impact of the Asian financial crisis. Studies in Economics and Finance, Vol. 25, no. 3, pp. 196-208.

Liow, K., (2016), The global financial crisis and cyclical co-movements of Asian financial markets. Journal of Property Investment \& Finance, Vol. 34, no. 5, pp. 465-495.

Lovell, Ca., (1993), Production Frontiers and Productive Efficiency. Production Frontiers and Productive Efficiency.

Luo, X., Raithel, S., Wiles, M.A., (2013), The impact of brand rating dispersion on firm value. Journal of Marketing Research, Vol. 50, no. 3, pp.399-415.

Majumdar, S. K., Chhibber, P., (1999), Capital structure and performance: Evidence from a transition economy on an aspect of corporate governance. Public Choice, Vol. 98, no. 3, pp. 287-305.

Majumdar, S.K., (1997), The impact of size and age on firm-level performance: some evidence from India. Review of industrial organization, Vol. 12, no. 2, pp. 231-241.

Memon, A.M., Tahir, I.M., (2012), Relative efficiency of manufacturing companies in Pakistan using Data Envelopment Analysis. International Journal of Business and Commerce, Vol. 1, no. 3, pp. 10-27.

Moutsianas, K. A., Kosmidou, K., (2016). Bank earnings volatility in the UK: Does size matter? A comparison between commercial and investment banks. Research in International Business and Finance, Vol. 38, pp. 137-150.

Mostafa, M.M., (2007), Evaluating the competitive market efficiency of top listed companies in Egypt. Journal of Economic Studies, Vol. 34, no. 5, pp. 430-452.

Mukherjee, K., (2008), Energy use efficiency in the Indian manufacturing sector: an inter state analysis. Energy policy, Vol. 36, no. 2, pp. 662-672.

Nadeem, M., Gan, C., Nguyen, C., (2017), Does intellectual capital efficiency improve firm performance in BRICS economies? A dynamic panel estimation. Measuring Business Excellence, Vol. 21, no. 1, 6585. doi:10.1108/mbe-12-2015-0055

Olatubi, W.O., Dismukes, D.E., (2000), A data envelopment analysis of the levels and determinants of coal-fired electric power generation performance. Utilities Policy, 9(2), 47-59.

Othman, F. M., Mohd-Zamil, N. A., Rasid, S. Z. A., Vakilbashi, A., Mokhber, M., (2016), Data Envelopment Analysis: A Tool of Measuring Efficiency in Banking Sector. International Journal of Economics and Financial, Vol. 6, no. 3. 
Park, C.W., Eisingerich, A.B., Pol, G., Park, J.W., (2013), The role of brand logos in firm performance. Journal of Business Research, Vol. 66, no. 2, pp. 180-187.

Rahman, A., Qayyum, A. Afza, T., Mazharlqbal, M. M., (2009), Efficiency Dynamics of Sugar Industry of Pakistan. The Pakistan Development Review. Vol. 48, no. 4. Pp. 921-938

Rezaie, K., Dalfard, V.M., Hatami-Shirkouhi, L., Nazari-Shirkouhi, S., (2013), Efficiencyappraisal and ranking of decision-making units using data envelopment analysis in the fuzzy environment: a case study of Tehran stock exchange. Neural Computing and Applications, Vol. 23, no. 1, pp. 1-17.

Rogova, E., Blinova, A., (2018), The Technical Efficiency of Russian Retail Companies: An Empirical Analysis. UniwersytetEkonomiczny w Krakowie, Vol. 5, no. 977, pp. 171-185, ISSN 1898-6447 e-ISSN

2545-3238, doi.org/10.15678/ZNUEK.2018.0977.0511

Seiford, L.M., Zhu, J., (1999), Profitability and marketability of the top 55 US commercial banks. Management Science, Vol. 45, no. 9, pp. 1270-1288.

Sigala. M., (2002), Developing and Benchmarking Internet Marketing Strategies in the Hotel Sector in Greece. Vol. 27, no. 4, https://doi.org/10.1177/10963480030274001

Shah, U. K., (2011), Organizational Legitimacy and the Strategic Bridging Ability of Green Alliances. Wiley Online Library, https://doi.org/10.1002/bse.706

Stavarek, D., (2006), Banking efficiency in the context of European integration. Eastern European Economics, Vol. 44, no. 4, pp. 5-31.

Wang, Z.H., Zeng, H.L., Wei, Y.M., Zhang, Y.X., (2012), Regional total factor energy efficiency: an empirical analysis of the industrial sector in China. Applied Energy, Vol. 97, pp. 115-123.

Zelenyuk, V., Zheka, V., (2006), Corporate governance and firm's efficiency: the case of a transitional country, Ukraine. Journal of Productivity Analysis, Vol. 25, no. 1, pp. 143-157. 


\begin{tabular}{|c|c|c|c|c|c|c|c|c|c|c|c|c|c|}
\hline \multicolumn{14}{|c|}{ Appendix A } \\
\hline \multicolumn{14}{|c|}{ DEA Analysis (Firm Efficiency Scores) } \\
\hline Company Name & 2004 & 2005 & 2006 & 2007 & 2008 & 2009 & 2010 & 2011 & 2012 & 2013 & 2014 & 2015 & 2016 \\
\hline Attock Cement & 1 & 1 & 1 & 1 & 1 & 1 & 1 & 1 & 1 & 1 & 1 & 1 & 1 \\
\hline Bestway Cement & 1 & 1 & 1 & 1 & 1 & 1 & 1 & 1 & 1 & 1 & 1 & 1 & 1 \\
\hline Cherat Cement & 0.989 & 1 & 1 & 1 & 0.998 & 1 & 1 & 1 & 1 & 1 & 1 & 1 & 1 \\
\hline D.G.K.Cement & 1 & 1 & 1 & 1 & 1 & 1 & 1 & 1 & 1 & 1 & 1 & 1 & 0.933 \\
\hline Dandot Cement & 0.961 & 1 & 1 & 1 & 1 & 1 & 1 & 1 & 1 & 1 & 1 & 1 & 0.868 \\
\hline Dewan Cement & 1 & 1 & 1 & 1 & 1 & 1 & 1 & 1 & 1 & 1 & 1 & 1 & 0.827 \\
\hline Fauji Cement & 1 & 1 & 1 & 1 & 1 & 1 & 1 & 1 & 1 & 1 & 1 & 1 & 1 \\
\hline Fecto Cement & 0.971 & 1 & 0.998 & 0.779 & 1 & 1 & 1 & 1 & 1 & 1 & 0.623 & 0.946 & 1 \\
\hline Gharibwal Cement & 1 & 1 & 1 & 0.99 & 1 & 1 & 1 & 1 & 1 & 1 & 1 & 1 & 0.998 \\
\hline Kohat Cement & 1 & 1 & 1 & 1 & 1 & 1 & 0.936 & 1 & 1 & 1 & 0.97 & 1 & 1 \\
\hline Lafarge Pak Cement & 1 & 1 & 1 & 1 & 1 & 1 & 1 & 1 & 1 & 1 & 1 & 1 & 1 \\
\hline Lucky Cement & 1 & 1 & 1 & 1 & 1 & 1 & 0.936 & 1 & 1 & 1 & 0.97 & 1 & 1 \\
\hline Pioneer Cement & 1 & 1 & 1 & 1 & 1 & 1 & 1 & 1 & 1 & 1 & 1 & 1 & 1 \\
\hline Ados Pakistan & 1 & 1 & 1 & 1 & 1 & 1 & 1 & 1 & 1 & 0.986 & 1 & 1 & 1 \\
\hline Bolan Casting & 1 & 1 & 1 & 1 & 1 & 1 & 1 & 1 & 1 & 1 & 0.824 & 1 & 1 \\
\hline Crescent Steel & 1 & 1 & 1 & 0.868 & 1 & 1 & 1 & 1 & 1 & 1 & 1 & 1 & 1 \\
\hline Dadex Eternit & 1 & 1 & 1 & 1 & 1 & 1 & 1 & 1 & 1 & 0.874 & 1 & 1 & 1 \\
\hline Huffaz Seamless & 1 & 1 & 1 & 0.868 & 1 & 1 & 1 & 1 & 1 & 1 & 1 & 1 & 1 \\
\hline Engro Corp & 1 & 1 & 1 & 1 & 1 & 1 & 1 & 1 & 1 & 1 & 1 & 1 & 1 \\
\hline Fauji Fert Bin & 1 & 1 & 1 & 1 & 1 & 1 & 1 & 1 & 1 & 1 & 1 & 1 & 1 \\
\hline Fauji Fert. & 1 & 1 & 1 & 1 & 1 & 1 & 1 & 1 & 1 & 1 & 1 & 1 & 1 \\
\hline Dawood Hercules & 1 & 0.607 & 1 & 1 & 1 & 1 & 1 & 1 & 1 & 1 & 1 & 1 & 1 \\
\hline Oil \& Gas Develp Co. Ltd. & 1 & 1 & 1 & 1 & 1 & 1 & 1 & 1 & 1 & 1 & 1 & 1 & 1 \\
\hline Pak Oilfields & 1 & 1 & 1 & 1 & 1 & 1 & 1 & 1 & 1 & 1 & 1 & 1 & 1 \\
\hline Pak Petroleum & 1 & 1 & 1 & 1 & 1 & 1 & 1 & 1 & 1 & 1 & 1 & 0.925 & 1 \\
\hline Mari Petroleum & 1 & 1 & 1 & 1 & 1 & 1 & 1 & 1 & 1 & 1 & 1 & 0.777 & 1 \\
\hline Attock Petroleum & 1 & 1 & 1 & 1 & 1 & 1 & 1 & 1 & 1 & 1 & 1 & 1 & 0.99 \\
\hline P.S.O. & 1 & 1 & 1 & 1 & 1 & 1 & 1 & 1 & 1 & 1 & 1 & 1 & 0.992 \\
\hline Shell Pakistan Ltd & 1 & 1 & 1 & 1 & 1 & 1 & 1 & 1 & 1 & 1 & 1 & 1 & 1 \\
\hline Sui Northern Gas & 1 & 1 & 0.968 & 1 & 1 & 1 & 1 & 1 & 1 & 1 & 1 & 1 & 1 \\
\hline Sui Southern Gas & 1 & 0.99 & 1 & 1 & 1 & 1 & 1 & 1 & 1 & 1 & 1 & 1 & 1 \\
\hline ALAbbasSugarXD & 1 & 1 & 1 & 1 & 1 & 0.63 & 1 & 1 & 1 & 1 & 0.784 & 1 & 1 \\
\hline Adam SugarXD & 0.806 & 0.852 & 1 & 0.767 & 1 & 0.546 & 1 & 1 & 1 & 1 & 1 & 1 & 0.841 \\
\hline Abdullah Shah & 0.809 & 1 & 1 & 0.797 & 0.941 & 0.546 & 1 & 1 & 1 & 1 & 0.874 & 1 & 1 \\
\hline ALNoorSugarXD & 1 & 0.718 & 1 & 0.797 & 0.968 & 0.63 & 1 & 1 & 1 & 1 & 0.668 & 1 & 1 \\
\hline Ansari Sugar & 1 & 1 & 1 & 1 & 1 & 0.546 & 1 & 1 & 0.874 & 1 & 0.943 & 1 & 1 \\
\hline Baba Farid & 1 & 1 & 1 & 1 & 0.852 & 1 & 1 & 1 & 0.979 & 1 & 1 & 0.859 & 1 \\
\hline
\end{tabular}




\begin{tabular}{|c|c|c|c|c|c|c|c|c|c|c|c|c|c|}
\hline \multicolumn{14}{|c|}{ DEA Analysis (Firm Efficiency Scores) } \\
\hline Company Name & 2004 & 2005 & 2006 & 2007 & 2008 & 2009 & 2010 & 2011 & 2012 & 2013 & 2014 & 2015 & 2016 \\
\hline ChashmaSugarXD & 1 & 1 & 1 & 1 & 0.901 & 1 & 0.898 & 0.921 & 1 & 0.995 & 0.943 & 0.811 & 1 \\
\hline Dewan Sugar & 0.987 & 1 & 0.918 & 1 & 0.618 & 1 & 1 & 0.946 & 0.979 & 1 & 1 & 1 & 1 \\
\hline FaranSugarXD & 1 & 1 & 0.679 & 1 & 1 & 1 & 0.898 & 1 & 1 & 1 & 1 & 0.855 & 0.885 \\
\hline Habib SugarXD & 0.856 & 1 & 0.608 & 1 & 0.627 & 1 & 1 & 1 & 1 & 0.965 & 1 & 0.754 & 0.932 \\
\hline HabibADM Ltd & 1 & 1 & 0.679 & 1 & 1 & 1 & 1 & 0.904 & 1 & 0.959 & 1 & 0.998 & 1 \\
\hline Husein Sugar Mills & 1 & 1 & 0.608 & 1 & 0.912 & 1 & 1 & 0.961 & 1 & 0.833 & 1 & 1 & 0.624 \\
\hline Haseeb Waqas Sugar & 1 & 1 & 1 & 0.973 & 0.962 & 1 & 1 & 1 & 1 & 1 & 1 & 0.998 & 1 \\
\hline Khairpur Sugar & 1 & 1 & 1 & 1 & 0.928 & 1 & 0.997 & 1 & 0.995 & 0.833 & 1 & 1 & 1 \\
\hline Mirpurkhas Sugar & 1 & 1 & 1 & 0.864 & 1 & 1 & 1 & 1 & 0.934 & 1 & 1 & 1 & 1 \\
\hline J.D.W.SugarXD & 1 & 1 & 1 & 1 & 0.809 & 1 & 1 & 1 & 1 & 0.991 & 1 & 1 & 0.752 \\
\hline Mehran SugarXD & 1 & 1 & 1 & 0.864 & 1 & 1 & 1 & 1 & 0.973 & 1 & 0.996 & 1 & 1 \\
\hline Noon SugarXD & 0.975 & 1 & 1 & 1 & 1 & 1 & 1 & 1 & 1 & 1 & 1 & 1 & 1 \\
\hline Mirza Sugar & 1 & 1 & 1 & 0.886 & 1 & 1 & 1 & 1 & 1 & 0.879 & 1 & 1 & 1 \\
\hline Shakarganj Limited & 1 & 0.543 & 1 & 0.806 & 1 & 1 & 1 & 1 & 1 & 1 & 1 & 1 & 1 \\
\hline Bawany Air Products & 1 & 0.701 & 0.848 & 1 & 1 & 1 & 1 & 1 & 0.993 & 1 & 0.512 & 1 & 0.922 \\
\hline Berger Paints & 1 & 0.364 & 1 & 1 & 1 & 1 & 1 & 1 & 0.961 & 1 & 0.499 & 0.751 & 1 \\
\hline Biafo Ind. & 1 & 0.818 & 0.886 & 1 & 1 & 1 & 0.986 & 1 & 0.989 & 1 & 0.262 & 1 & 1 \\
\hline Buxly Paints & 1 & 1 & 1 & 1 & 1 & 1 & 1 & 0.994 & 1 & 1 & 0.77 & 0.781 & 1 \\
\hline Colgate Palmolive & 1 & 0.818 & 0.995 & 1 & 1 & 0.958 & 1 & 1 & 1 & 1 & 0.688 & 1 & 1 \\
\hline Data Agro & 1 & 1 & 1 & 1 & 0.967 & 1 & 0.868 & 1 & 1 & 1 & 1 & 0.977 & 1 \\
\hline Dynea Pakistan & 1 & 1 & 1 & 1 & 1 & 0.889 & 0.788 & 1 & 1 & 0.697 & 0.688 & 0.959 & 1 \\
\hline ICI Pakistan & 1 & 0.856 & 1 & 1 & 1 & 1 & 1 & 0.482 & 1 & 0.626 & 1 & 1 & 1 \\
\hline Ittehad Chem. & 0.959 & 0.74 & 1 & 1 & 1 & 0.488 & 0.788 & 1 & 1 & 1 & 1 & 0.492 & 0.989 \\
\hline Leiner Pak Gelat & 1 & 1 & 1 & 1 & 1 & 1 & 1 & 1 & 1 & 1 & 0.751 & 1 & 0.981 \\
\hline Lotte Chemical & 1 & 0.928 & 1 & 1 & 1 & 0.854 & 1 & 1 & 1 & 1 & 0.815 & 1 & 0.995 \\
\hline NimirInd.Chem. & 1 & 1 & 1 & 1 & 1 & 0.728 & 0.746 & 0.935 & 1 & 0.727 & 0.752 & 1 & 1 \\
\hline Sardar Chemical & 1 & 1 & 1 & 0.997 & 0.824 & 0.981 & 0.723 & 0.732 & 1 & 1 & 1 & 1 & 1 \\
\hline Pak.P.V.C. & 1 & 1 & 0.94 & 0.829 & 0.771 & 1 & 0.466 & 1 & 1 & 0.727 & 0.348 & 1 & 1 \\
\hline Pak Gum \& Chem. & 1 & 1 & 1 & 1 & 1 & 0.888 & 0.936 & 0.732 & 1 & 1 & 0.256 & 1 & 1 \\
\hline Nimir Resins & 1 & 1 & 1 & 1 & 0.616 & 1 & 1 & 1 & 1 & 1 & 1 & 1 & 0.995 \\
\hline Shaffi Chemical & 1 & 1 & 0.957 & 1 & 0.917 & 0.888 & 1 & 1 & 1 & 1 & 1 & 0.907 & 1 \\
\hline Sitara Chemical & 1 & 1 & 0.82 & 0.957 & 1 & 1 & 0.868 & 1 & 1 & 0.979 & 1 & 1 & 1 \\
\hline Abbott Laboratories & 0.29 & 1 & 1 & 1 & 1 & 1 & 1 & 1 & 0.992 & 0.873 & 1 & 0.446 & 1 \\
\hline WahNoble & 1 & 1 & 1 & 0.94 & 1 & 1 & 0.919 & 1 & 0.943 & 0.656 & 1 & 0.74 & 1 \\
\hline Ismail Ind & 0.902 & 1 & 1 & 1 & 1 & 1 & 1 & 1 & 0.881 & 1 & 0.226 & 1 & 1 \\
\hline MithchellsFruit & 1 & 1 & 1 & 1 & 1 & 1 & 0.791 & 1 & 0.78 & 1 & 1 & 1 & 1 \\
\hline Murree Brewery & 0.95 & 0.991 & 1 & 1 & 1 & 1 & 1 & 1 & 0.609 & 1 & 1 & 1 & 1 \\
\hline National Foods & 0.601 & 0.982 & 1 & 1 & 1 & 0.945 & 1 & 1 & 1 & 0.987 & 1 & 1 & 1 \\
\hline Nestle Pakistan & 0.788 & 1 & 0.975 & 0.943 & 1 & 0.648 & 1 & 1 & 1 & 1 & 1 & 1 & 0.949 \\
\hline
\end{tabular}


Studies in Business and Economics no. 14(3)/2019

\begin{tabular}{|c|c|c|c|c|c|c|c|c|c|c|c|c|c|}
\hline \multicolumn{14}{|c|}{ DEA Analysis (Firm Efficiency Scores) } \\
\hline Company Name & 2004 & 2005 & 2006 & 2007 & 2008 & 2009 & 2010 & 2011 & 2012 & 2013 & 2014 & 2015 & 2016 \\
\hline Quice Food & 1 & 0.89 & 0.937 & 1 & 1 & 0.879 & 1 & 0.969 & 1 & 1 & 1 & 1 & 1 \\
\hline Rafhan Maize & 1 & 1 & 1 & 0.943 & 1 & 1 & 0.614 & 0.817 & 0.576 & 1 & 1 & 1 & 0.904 \\
\hline Shezan Inter. & 1 & 1 & 0.937 & 1 & 1 & 1 & 0.763 & 1 & 0.474 & 1 & 1 & 1 & 0.819 \\
\hline Shield Corp. & 1 & 1 & 1 & 1 & 1 & 1 & 0.84 & 1 & 0.576 & 1 & 0.988 & 0.849 & 0.931 \\
\hline Treet Corp & 1 & 1 & 1 & 1 & 1 & 0.9 & 0.963 & 1 & 0.474 & 1 & 1 & 1 & 1 \\
\hline Unilever Foods & 1 & 1 & 0.993 & 1 & 1 & 1 & 0.888 & 1 & 1 & 0.999 & 1 & 0.671 & 1 \\
\hline ZIL Limited & 1 & 1 & 0.986 & 0.742 & 1 & 0.988 & 0.802 & 1 & 1 & 0.985 & 1 & 0.662 & 1 \\
\hline Goodluck Ind. & 1 & 1 & 1 & 0.941 & 1 & 0.929 & 0.888 & 1 & 1 & 0.977 & 1 & 0.755 & 1 \\
\hline Gillette Pak & 1 & 1 & 1 & 1 & 1 & 1 & 0.802 & 1 & 1 & 0.969 & 1 & 1 & 1 \\
\hline Clover Pakistan & 1 & 1 & 0.965 & 1 & 0.637 & 1 & 1 & 1 & 1 & 1 & 1 & 1 & 1 \\
\hline Artistic Denim & 1 & 1 & 0.981 & 0.765 & 0.279 & 1 & 1 & 1 & 0.898 & 1 & 1 & 1 & 1 \\
\hline Ahmed Hassan & 1 & 1 & 1 & 1 & 0.226 & 1 & 1 & 1 & 1 & 1 & 1 & 0.585 & 1 \\
\hline $\begin{array}{l}\text { AzgardNine(LeglerNafees } \\
\text { Denim) }\end{array}$ & 1 & 1 & 0.824 & 1 & 1.197 & 1 & 0.554 & 1 & 1 & 1 & 1 & 0.59 & 1 \\
\hline (Colony) Sarhad & 1 & 0.885 & 1 & 1 & 0.168 & 1 & 1 & 1 & 1 & 1 & 1 & 0.59 & 1 \\
\hline (Colony) Thal & 1 & 0.885 & 1 & 1 & 0.812 & 0.239 & 1 & 0.951 & 1 & 0.852 & 1 & 0.288 & 1 \\
\hline Dawood Law & 1 & 1 & 0.931 & 1 & 1 & 0.15 & 0.418 & 0.81 & 1 & 0.973 & 1 & 0.125 & 1 \\
\hline Faisal Spinning & 1 & 1 & 0.935 & 1 & 0.474 & 0.137 & 0.882 & 0.824 & 1 & 1 & 1 & 0.229 & 1 \\
\hline Fateh Sports & 1 & 1 & 1 & 0.72 & 1 & 0.138 & 1 & 0.831 & 1 & 1 & 1 & 1 & 0.999 \\
\hline Fateh Textile Mills & 1 & 1 & 0.998 & 1 & 0.738 & 0.138 & 1 & 0.826 & 1 & 1 & 1 & 1 & 1 \\
\hline Gul Ahmed & 1 & 1 & 1 & 1 & 0.738 & 0.138 & 1 & 0.925 & 1 & 1 & 1 & 1 & 1 \\
\hline Ghazi Fabrics & 1 & 1 & 1 & 1 & 1 & 0.64 & 1 & 1 & 1 & 1 & 0.954 & 1 & 0.971 \\
\hline Hala Enterprise & 1 & 0.668 & 0.998 & 1 & 1 & 0.788 & 1 & 1 & 0.703 & 1 & 0.901 & 1 & 1 \\
\hline Hamid Textile & 1 & 1 & 0.867 & 1 & 1 & 0.125 & 1 & 1 & 1 & 1 & 1 & 1 & 0.888 \\
\hline Jubilee Spinning & 1 & 1 & 1 & 0.685 & 1 & 0.125 & 1 & 1 & 0.419 & 1 & 1 & 1 & 0.931 \\
\hline Khyber Textile & 1 & 1 & 1 & 1 & 1 & 1 & 1 & 1 & 0.701 & 1 & 1 & 1 & 1 \\
\hline Kohinoor Textile & 0.987 & 0.987 & 1 & 1 & 1 & 0.788 & 1 & 1 & 0.499 & 1 & 1 & 1 & 0.857 \\
\hline Masood Textile & 0.988 & 1 & 0.99 & 1 & 1 & 1 & 1 & 1 & 1 & 1 & 1 & 1 & 1 \\
\hline Mian Textile & 0.789 & 1 & 1 & 1 & 1 & 1 & 1 & 1 & 1 & 0.974 & 1 & 1 & 0.921 \\
\hline Mubarak Textile & 0.811 & 0.987 & 0.95 & 1 & 1 & 0.917 & 1 & 1 & 1 & 0.333 & 1 & 1 & 0.921 \\
\hline Nishat Mills Ltd & 1 & 1 & 0.782 & 1 & 1 & 0.807 & 1 & 1 & 0.924 & 0.226 & 1 & 1 & 0.921 \\
\hline Allied Bank Ltd & 1 & 1 & 0.263 & 0.486 & 0.505 & 0.612 & 1 & 1 & 1 & 1 & 0.978 & 0.805 & 1 \\
\hline Askari Bank & 0.913 & 1 & 0.274 & 0.412 & 0.483 & 0.779 & 1 & 1 & 0.747 & 0.951 & 1 & 0.414 & 1 \\
\hline Bank Al-Falah & 1 & 0.744 & 0.221 & 0.56 & 0.399 & 1 & 1 & 1 & 0.855 & 0.876 & 0.989 & 1 & 1 \\
\hline Bank AL-Habib & 1 & 0.615 & 0.739 & 0.788 & 1 & 1 & 1 & 0.94 & 0.969 & 0.85 & 1 & 1 & 1 \\
\hline B.O.Punjab & 0.68 & 0.434 & 0.927 & 1 & 1 & 1 & 1 & 0.903 & 1 & 0.832 & 1 & 1 & 1 \\
\hline Faysal Bank & 0.975 & 0.465 & 0.914 & 1 & 1 & 1 & 0.727 & 0.887 & 0.983 & 0.793 & 1 & 1 & 1 \\
\hline St.Chart.Bank & 0.962 & 0.443 & 1 & 1 & 1 & 0.964 & 0.856 & 0.997 & 0.848 & 1 & 1 & 1 & 0.476 \\
\hline National Bank & 1 & 1 & 1 & 1 & 1 & 0.422 & 0.71 & 0.966 & 1 & 1 & 1 & 1 & 1 \\
\hline MCB Bank & 1 & 0.752 & 1 & 1 & 1 & 0.357 & 0.693 & 0.945 & 1 & 1 & 1 & 0.947 & 0.25 \\
\hline Habib Bank & 1 & 1 & 1 & 1 & 0.58 & 0.347 & 0.481 & 1 & 1 & 1 & 1 & 0.645 & 0.892 \\
\hline Habib Metropol. & 1 & 1 & 1 & 1 & 0.489 & 0.487 & 0.412 & 1 & 1 & 1 & 0.964 & 0.735 & 0.883 \\
\hline United Bank & 1 & 1 & 1 & 1 & 0.378 & 0.499 & 0.42 & 1 & 1 & 1 & 0.781 & 1 & 1 \\
\hline Silk Bank Ltd & 1 & 1 & 1 & 1 & 0.353 & 1 & 1 & 1 & 1 & 0.684 & 0.739 & 0.983 & 0.726 \\
\hline Meezan Bank & 1 & 1 & 0.969 & 1 & 0.298 & 1 & 1 & 0.879 & 1 & 0.671 & 0.592 & 1 & 0.549 \\
\hline Bankislami Pak & 1 & 1 & 1 & 0.402 & 0.288 & 0.782 & 1 & 0.956 & 1 & 1 & 0.603 & 1 & 0.549 \\
\hline
\end{tabular}

